\title{
KONTRIBUSI ADOPSI TEKNOLOGI INFORMASI TERHADAP KINERJA USAHA KECIL MENENGAH DI INDONESIA STUDI KASUS: BANK PERKREDITAN RAKYAT
}

\author{
Grandys Frieska Prassida, Apol Pribadi Subriadi \\ Jurusan Sistem Informasi, Fakultas Teknologi Informasi, Institut Teknologi Sepuluh Nopember \\ Kampus Keputih, Sukolio Surabaya 60111 \\ Telp: (031) 5999944, Fax: (031) 5964965 \\ E-mail: grandysfp@gmail.com
}

\begin{abstract}
Several previous studies indicate that IT adoption by SMEs is still low compared to large companies. Caused by their limitations, IT adoption that are not handled properly can have a certain impact to the performance of SMEs. Therefore, this study seeks to provide a more comprehensive understanding of concept of IT adoption in SMEs, by looking at the factors which affect IT adoption, consider the stages in IT adoption, until it can review the contribution of IT adoption on the performance of SMEs. By using a component-based approach with Generalized Structured Component Analysis (GSCA) tool, this study get the results that internal and external factors are not shown to influence the IT adoption decision, indicated by the value of the path coefficient is not significant. Next, the IT adoption decisions in this study has been able to prove significantly affect the implementation of IT adoption. Correlation on these two variables have the highest value and significant, which is indicated by the value estimate on the path coefficients of 0.393 and the critical ratio of 2.48 at the 0.05 level $(P<0.05)$. As for the results of the implementation of IT adoption, it was not proven to affect the performance. Implementation of IT adoption has not been able to make significant contributions to the performance of $B P R$, as evidenced by the results in the adoption of IT implementation variable contributed only $3.9 \%$ of the performance variable.
\end{abstract}

\section{Abstrak}

Beberapa penelitian terdahulu menunjukkan bahwa adopsi TI oleh UKM masih rendah dibandingkan dengan perusahaan-perusahaan besar. Disebabkan oleh beberapa keterbatasan, maka adopsi TI yang tidak ditangani dengan baik dapat memiliki dampak tertentu bagi kinerja UKM. Oleh karena itu, penelitian ini berusaha untuk dapat memberikan pemahaman yang lebih komprehensif terhadap konsep adopsi TI di UKM, dengan melihat faktor-faktor yang mempengaruhi adopsi TI, mempertimbangkan tahapan dalam adopsi TI, hingga akhirnya dapat meninjau kontribusi adopsi TI terhadap kinerja UKM. Dengan menggunakan pendekatan component based dengan alat bantu Generalized Structured Component Analysis (GSCA), penelitian ini mendapatkan hasil bahwa pada faktor internal maupun eksternal tidak terbukti berpengaruh terhadap keputusan adopsi TI, ditunjukkan dengan nilai koefisien jalur yang tidak siginifikan. Berikutnya, keputusan adopsi TI dalam penelitian ini telah mampu dibuktikan secara signifikan berpengaruh terhadap implementasi adopsi TI. Korelasi pada kedua variabel ini memiliki nilai tertinggi dan signifikan, yakni ditunjukkan dengan nilai estimate pada path coefficients sebesar 0,393 dan critical ratio 2,48 pada level 0,05 ( $p<0.05)$. Sedangkan untuk hasil dari implementasi adopsi TI, ternyata tidak terbukti berpengaruh terhadap kinerja. Implementasi adopsi TI belum bisa memberikan kontribusi besar terhadap kinerja BPR, terbukti dengan hasil pada variabel implementasi adopsi TI yang hanya memberikan kontribusi sebesar 3,9\% saja terhadap variabel kinerja.

Kata kunci: kontribusi, adopsi, teknologi informasi, kinerja, UKM

\section{PENDAHULUAN}

Usaha Kecil Menengah (UKM) memainkan peran penting dalam perekonomian Indonesia. Dalam menghadapi perekonomian yang didominasi oleh globalisasi dan persaingan kompetitif, maka inisiatif untuk meningkatkan daya saing UKM perlu terus diupayakan. Adopsi Teknologi Informasi (TI) menjadi sebuah solusi untuk meningkatkan transformasi bisnis, ketepatan dan efisiensi pertukaran informasi, juga untuk memperluas jaringan pemasaran dan market share UKM (Khristianto, 2012). Beberapa penelitian terdahulu menunjukkan bahwa adopsi TI oleh UKM masih rendah bila dibandingkan dengan perusahaan besar. Hal tersebut disebabkan oleh berbagai faktor diantaranya 
terkait modal, sumber daya, dan penguasaan TI (Levy, 2005). Di Indonesia, Putranto dkk. (2003) menemukan bahwa salah satu faktor penyebab kegagalan adopsi TI oleh UKM yaitu kurangnya kemampuan untuk memperoleh solusi TI yang tepat yang penting bagi bisnis. Walaupun demikian, Subriadi dkk. (2013) membuktikan bahwa ukuran perusahaan tidak mempengaruhi kontribusi TI terhadap kinerja yang diharapkan (Subriadi, 2013). Hal ini didukung pula dengan fakta bahwa seringkali kemajuan teknologi dapat diadopsi dan dimanfaatkan oleh perusahaan kecil yang lebih lincah dan cepat dibandingkan dengan perusahaan besar. Banyak penelitian terdahulu mengakui bahwa ada banyak faktor yang berkontribusi terhadap proses adopsi TI dan mendorong UKM untuk mengadopsi TI sebagai kebutuhan (Sarosa, dkk., 2003). Adanya perbedaan definisi dan konsep adopsi TI dari beberapa penelitian, juga masih sedikitnya penelitian yang menguji kontribusi adopsi TI terhadap kinerja UKM di Indonesia, maka pertanyaan besar yang ingin dijawab melalui penelitian ini yaitu "bagaimana konsep adopsi TI oleh UKM di Indonesia bila ditinjau dari faktor pengaruh dan kontribusinya terhadap kinerja UKM?".

Penelitian ini bertujuan untuk menganalisis kontribusi adopsi TI terhadap kinerja UKM di Indonesia, diawali dari perspektif faktor yang mempengaruhi keputusan adopsi TI, kemudian tingkat adopsi TI dalam UKM dengan memperhatikan tahapan proses adopsi. Kontribusi teoritis penelitian ini diperoleh dari pengembangan model konseptual yang diusulkan. Sedangkan kontribusi praktis ditujukan kepada manajemen puncak UKM, agar hasil penelitian ini dapat membantu UKM untuk lebih siap dalam mengadopsi TI sehingga dapat memperoleh manfaat nyata dari adopsi TI dalam bisnisnya.

\subsection{Organizational Behavior (Perilaku Organisasi)}

Sebuah model kontingensi perilaku organisasi menunjukkan perkembangan perilaku organisasi sebagai individu, kelompok, dan sistem organisasi (Robbins, 2003). Pendekatan konti-ngensi menyiratkan penilaian setiap subsistem termasuk struktur, fungsi teknis dan proses, budaya organisasi, tujuan dan nilai, dan fungsi manajemen di seluruh spektrum organisasi. Pengetahuan ini dapat diterapkan untuk membuat organisasi bekerja lebih efektif, meningkatkan kepuasan kerja, kinerja dan produktivitas, meningkatkan motivasi kerja, dan mengurangi ketidakhadiran dan turnover.

\subsection{Innovation Diffusion and Innovation Decision Process Model (IDPM)}

Penelitian adopsi TI menggunakan tahapan IDPM Rogers untuk menemukan faktor yang mempengaruhi proses adopsi keseluruhan dalam konteks tertentu atau untuk menjelaskan peran faktor tertentu dalam proses adopsi tertentu (AlGahtani, 2007). IDPM didasarkan pada teori komunikasi, dimana inovasi tersebut dikomunikasikan kepada audiens (pengadopsi potensial). Tahapan IDPM yang didefinisikan oleh Rogers (1995), meliputi Pengetahuan (Unit pengambilan keputusan terkait keberadaan inovasi), Persuasi (Unit pengambilan keputusan yang membentuk pendapat terhadap inovasi), Keputusan (Unit pengambilan keputusan yang memutuskan baik untuk menolak atau menerima adopsi inovasi), Implementasi (Unit pengambilan keputusan yang benar-benar menggunakan inovasi), Konfirmasi (Unit pengambilan keputusan yang menegaskan atau membalikkan keputusan untuk menolak atau mengadopsi inovasi yang dibuat pada tahap sebelumnya).

\subsection{Information System Success Model}

Information System Success Model ini ditargetkan untuk dapat menilai keberhasilan Sistem Informasi (SI). Model ini dapat dimodifikasi untuk memenuhi persyaratan yang ditetapkan oleh beberapa jenis SI dari sudut pandang yang berbeda. Peneliti yang ingin menerapkan model D \& M harus memiliki pemahaman tentang sistem informasi dan organisasi yang akan diteliti. DeLone \& McLean (2003) memberikan enam dimensi yang dapat dijadikan ukuran keberhasilan, yakni Kualitas Sistem (System Quality), Kualitas Informasi (Information Quality), Kualitas Layanan (Service Quality), Penggunaan sistem (Use/Intention to Use), Kepuasan pengguna (User Satisfaction), dan Keuntungan (Net Benefit).

\subsection{Kajian Penelitian Terdahulu}

Kajian pustaka pada bagian ini mengkaji beberapa penelitian terdahulu untuk mengambil celah yang dapat diteliti lebih lanjut maupun guna menguatkan hasil dari penelitian yang disesuaikan dengan kebutuhan pada penelitian ini.

Ghobakhloo et al. (2011) mengembangkan suatu kerangka terpadu yang digunakan untuk mengklasifikasikan berbagai isu dan relatif faktor terhadap proses adopsi TI dalam UKM. Berdasarkan tinjauan literatur terkait dengan adopsi TI yang banyak ditemui dalam dua dekade terakhir ini, model yang dihasilkan dalam penelitian Ghobakhloo et al (2011) terdiri dari aspek yang berbeda dari faktor adopsi TI internal dan eksternal. Faktor internal meliputi manajemen 
puncak, sumber daya organisasi, pengguna akhir, karakteristik dan perilaku organisasi, dan solusi TI itu sendiri. Sedangkan faktor eksternal terdiri dari tekanan eksternal dan kompetitif, pelanggan dan pemasok, konsultan TI eksternal dan vendor, dan juga pemerintah. Penelitian ini menambah pengetahuan lebih lanjut untuk literatur penelitian mengenai adopsi TI oleh UKM yang lebih komprehensif dalam menyelidiki faktor yang dapat mempengaruhi UKM tersebut untuk mengadopsi TI.

Wang et al. (2004) mengusulkan tingkat adopsi TI menjadi salah satu bagian penting dalam model untuk mengevaluasi status adopsi TI pada perusahaan inti dan perusahaan afiliasi dalam jaringan bisnis rantai pasokan. Penulis menyadari sulitnya untuk mengevaluasi dampak langsung dan manfaat dari adopsi TI berdasarkan kinerja bisnis. Penelitian Wang et al. (2004) ini berusaha untuk menyelidiki motivasi perusahaan dilihat dari internal dan eksternalnya terhadap tingkat adopsi TI. Bila ditinjau dari konstruk model yang dikembangkan, Wang et al. (2004) membagi tingkat adopsi TI menjadi lima tingkatan, yakni Fungsi Esensial (Dokumentasi), Internal Departemen/Proses Operasi, Lintas Departemen/Integrasi Multi-proses, Enterprise Integration Process (EIP), B2B Integration/Kolaborasi Bisnis.

Ogalo et al. (2011) melakukan kajian secara empiris yang bertujuan untuk menilai hubungan antara adopsi Information Communication Technology (ICT) dan kinerja dari usaha kecil di Kisumu City. penelitian yang dilakukan Ogalo et al. (2011) ini berupaya untuk mengetahui jumlah usaha kecil yang telah mengadopsi ICT dalam bisnisnya, mengidentifikasi tingkat adopsi ICT oleh usaha kecil di kota Kisumu, kemudian menguji hubungan antara adopsi ICT dan kinerja usaha kecil di Kisumu City. Hasilnya menegaskan bahwa segala faktor adopsi dan implementasi harus ditangani dengan serius sebelum perusahaan bisa memperoleh potensi penuh dari adopsi ICT.

Sarosa (2007) mengidentifikasi proses adopsi TI dalam UKM di Indonesia. Berdasarkan literatur terdahulu yang telah menunjukkan faktor-faktor yang mempengaruhi adopsi TI, dari unsur UKM dan proses interaktif TI, Sarosa (2007) mengembangkan model awal dari proses adopsi TI. Menurut Sarosa (2007), tidak cukup untuk memahami faktor-faktor yang mempengaruhi adopsi TI, tetapi juga harus mengetahui bagaimana faktor-faktor tersebut berinteraksi. Oleh karena itu, dalam penelitian ini dilakukan eksplorasi adopsi TI sebagai suatu proses.

\section{METODOLOGI}

Kerangka konseptual merupakan penjelasan yang menyeluruh tentang teori yang menjadi acuan dasar yang dipadukan dengan hasil penelitianpenelitian yang telah ada sebelumnya sehingga memunculkan sebuah gagasan atas suatu permasalahan untuk dapat dikaji lebih lanjut.

\subsection{Konstruk Konseptual Model}

Konsep adopsi TI yang disepakati dalam penelitian ini yakni adopsi TI yang tidak hanya melibatkan penerimaan TI sebagai alat untuk mendukung bisnis, tetapi juga melibatkan implementasi aktual dan penggunaan komponen TI. Sehingga pengetahuan terkait perilaku UKM selama mengadopsi TI perlu diperhatikan. Dengan mengacu pada teori IDPM Rogers (1995), tahapan proses adopsi TI yang menjadi fokus ialah pada tahap keputusan dan implementasi. Tahap awal, yakni pengetahuan dan persuasi, diterjemahkan menjadi tahapan untuk menganalisis faktor-faktor yang dapat mempengaruhi keputusan untuk mengadopsi TI. Sedangkan tahap konfirmasi, dalam penelitian ini meninjau pengaruh implementasi adopsi TI terhadap kinerja UKM.

Sebuah kerangka kerja telah disusun dan digunakan untuk mengklasifikasikan berbagai macam isu dan faktor-faktor yang mempengaruhi proses adopsi TI. Kerangka tersebut mengelompokkan faktor-faktor ke dalam aspek internal dan eksternal UKM, dengan tinjauan terhadap literatur yang telah ada selama dua dekade terakhir (Ghobakhloo, 2011). Adopsi TI dapat dikaitkan erat dengan keberhasilan atau kegagalan dalam prosesnya. Oleh karena itu, dengan mengacu pada teori IS Success Model DeLone \& McLean, penelitian ini mengadaptasi variabel intention to use/use yang dapat mempengaruhi net benefit. Dalam hal ini, net benefit diartikan sebagai kinerja (performance) UKM yang ditinjau dari market share dan operasionalnya. Maka, kerangka konseptual yang diusulkan dalam penelitian ini dapat dilihat pada Gambar 1 di bawah ini.

Variabel Faktor Internal dalam penelitian ini meliputi manajemen puncak, sumber daya perusahaan, pengguna akhir, karakteristik dan perilaku organisasi, dan solusi TI. Faktor Eksternal terdiri dari pelanggan dan supplier (bank lain), lingkungan kompetitif, konsultan TI luar dan vendor, serta pemerintah. Keputusan Adopsi TI dalam hal ini diasumsikan sebagai kondisi TI yang siap digunakan dalam internal UKM, namun TI tersebut belum mulai digunakan. 


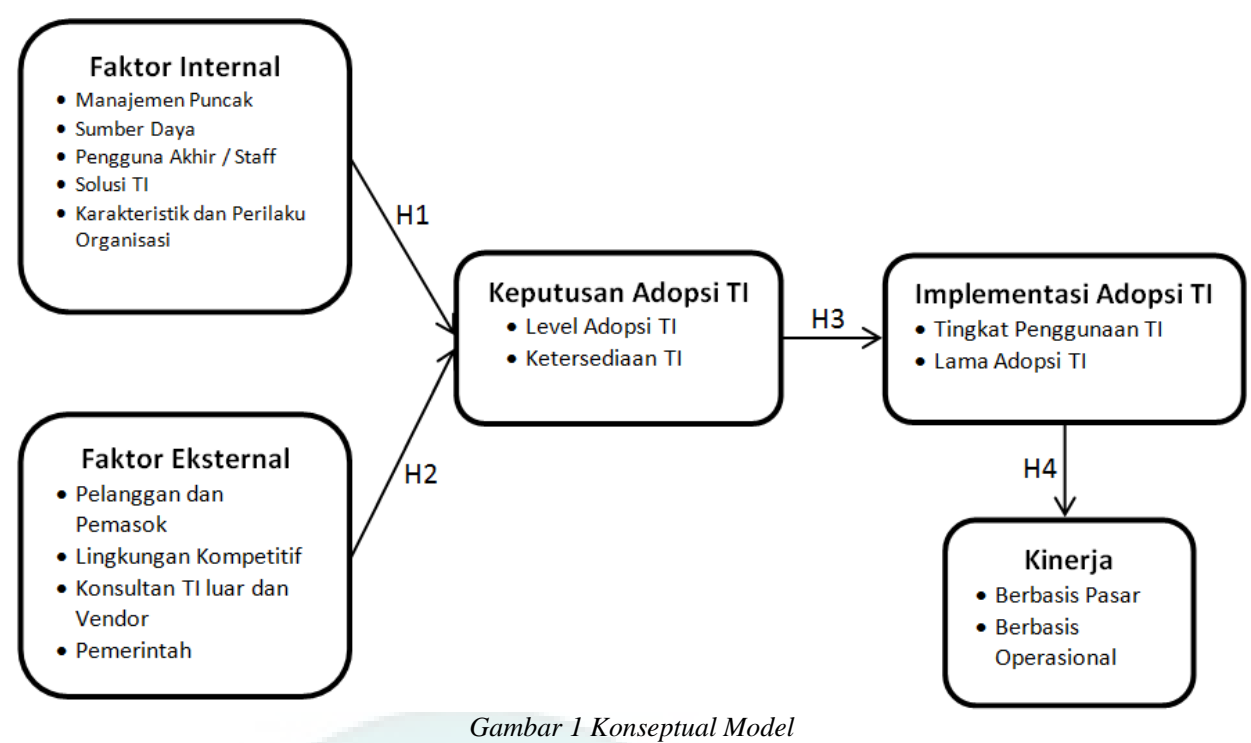

Keputusan tersebut ditandai dengan pengadaan TI pada level yang sesuai dengan kebutuhan, sehingga TI dipastikan telah tersedia dalam UKM. Implementasi adopsi TI diterjemahkan sebagai penggunaan TI untuk mendukung proses bisnis UKM dengan tujuan memperoleh keuntungan bagi bisnisnya. Sedangkan Kinerja yang dimaksudkan dalam penelitian ini merupakan salah satu indikator yang menggambarkan pencapaian UKM terhadap tujuan bisnisnya yang mendapat pengaruh dari adanya adopsi TI.

\subsection{Hipotesis Penelitian}

Hipotesis 1 (H1): Faktor internal berpengaruh terhadap keputusan adopsi TI oleh UKM

Faktor internal, yang biasanya dikontrol oleh manajemen UKM, penting diperhatikan ketika UKM akan mengadopsi TI. Penelitian ini mengajukan hipotesis yang menegaskan adanya pengaruh faktor internal terhadap keputusan adopsi TI oleh UKM.

Hipotesis 2 (H2): Faktor eksternal berpengaruh terhadap keputusan adopsi TI oleh UKM

Faktor eksternal sangat penting bagi keberhasilan adopsi TI di UKM karena bisnis ini umumnya memiliki keterbatasan internal. Oleh karena itu, penelitian ini mengajukan hipotesis yang menegaskan adanya pengaruh faktor eksternal terhadap keputusan adopsi TI oleh UKM.

Hipotesis 3 (H3): Keputusan adopsi TI berpengaruh terhadap implementasi adopsi TI

Keputusan untuk adopsi TI dalam penelitian ini diartikan sebagai suatu kondisi dimana UKM menentukan level adopsi TI hingga solusi TI yang dipilih tersebut telah tersedia di dalam UKM, namun belum digunakan. Hal tersebut yang akan mempengaruhi tahap selanjutnya, yakni implementasi adopsi TI. Sehubungan dengan itu, penelitian ini mengajukan hipotesis yang menegaskan adanya pengaruh keputusan adopsi TI terhadap implementasi adopsi TI di UKM.

Hipotesis 4 (H4): Implementasi adopsi TI berpengaruh terhadap kinerja UKM

Banyak penelitian menemukan hubungan yang signifikan antara penggunaan TI dan keuntungan bersih yang diukur dengan perbaikan dalam kinerja. Penelitian ini ingin menguatkan hasil beberapa penelitian sebelumnya yang menyatakan bahwa implementasi TI dapat memberikan pengaruh pada kinerja UKM, sesuai dengan hipotesis yang diajukan di atas.

\section{HASIL DAN PEMBAHASAN}

Obyek yang ditetapkan dalam penelitian ini yaitu Usaha Kecil Menengah (UKM) di Indonesia. Definisi UKM mengacu pada UU No 20 Tahun 2008, dimana kriterianya dilihat dari jumlah kekayaan bersih atau hasil penjualan tahunan. Kriteria lain dari UKM yang dipilih sebagai obyek dalam penelitian ini yakni satu jenis industri yang telah menggunakan TI untuk menunjang fungsi core business (bisnis utama) maupun non-core business yakni minimal fungsi-fungsi keuangan, sumber daya manusia, dan pemasaran. Berdasarkan kriteria-kriteria yang telah diuraikan, maka penelitian ini menyepakati Bank Perkreditan Rakyat (BPR) sebagai fokus obyek yang sesuai dengan kebutuhan penelitian. Unit yang analisis dalam penelitian ini yaitu BPR yang berada di wilayah Gerbangkertosusila, yakni Gresik, Bangkalan, Mojokerto, Surabaya, Sidoarjo, dan Lamongan. Jumlah populasi ditetapkan dengan mengambil kantor pusat BPR yang berada di setiap wilayah tersebut. Menurut situs Bank Indonesia (http://bi.go.id), terdapat sejumlah 101 BPR yang berada di wilayah Gerbangkertosusila. 
Instrumen yang digunakan dalam penelitian ini terdiri dari item pernyataan yang dirancang sesuai dengan indikator dan sub-indikator dari variabel-variabel yang ada dalam model konseptual. Skala Likert yang digunakan untuk mengukur atau menilai jawaban dari tiap item pernyataan menggunakan rentang nilai $1-5$, dimana semakin besar nilai menunjukkan jawaban yang semakin positif dan sebaliknya. Pengujian awal terhadap instrumen penelitian dilakukan pada 30 responden, yaitu manajemen puncak/CEO dan karyawan BPR. Pengujian instrumen penelitian dilakukan dengan menggunakan alat bantu perangkat lunak SPSS for Windows versi 17.

\subsection{Hasil Pengujian Awal Instrumen}

Uji awal dilakukan pada minimal jumlah sampel yang telah ditetapkan sebelumnya yakni pada 30 responden (masing-masing pada Direksi dan Karyawan BPR). Uji validitas terhadap semua item indikator menunjukkan nilai Korelasi Pearson (product moment) lebih dari 0,3 dan signifikan pada level $\alpha=1 \%$ atau $\alpha=5 \%$. Demikian pula untuk uji reliabilitas terhadap semua item indikator menunjukkan nilai Cronbach Alpha lebih dari 0,6. Dengan demikian, uji awal terhadap instrumen penelitian ini dapat dinyatakan telah valid dan reliabel, sehingga dapat digunakan untuk pengolahan instrumen selanjutnya.

Uji selanjutnya dilakukan untuk mengevaluasi asumsi pada GSCA yang berhubungan dengan penyusunan model, yakni hubungan antar variabel laten di dalam konseptual model. Asumsi hubungan tersebut diketahui dengan uji linieritas, yakni melalui metode Curve Estimation pada SPSS. Terdapat empat hubungan antar variabel yang terdapat dalam konseptual model, yakni Faktor Internal terhadap Keputusan Adopsi TI, Faktor Eksternal terhadap Keputusan Adopsi TI, Keputusan Adopsi TI terhadap Implementasi TI, dan Implementasi TI terhadap Kinerja. Hasilnya menunjukkan bahwa seluruh hubungan antar variabel dalam model memiliki hubungan linier, dimana hubungan Faktor Internal terhadap Keputusan Adopsi TI, Faktor Eksternal terhadap Keputusan Adopsi TI, dan Keputusan Adopsi TI terhadap Implementasi TI dibuktikan dengan tingkat signifikansi di bawah 5\% $(\mathrm{p}<0,05)$. Sedangkan satu hubungan antara Implementasi TI terhadap Kinerja dinyatakan linier dengan asumsi yakni meskipun tingkat signifikansi lebih dari 5\% namun setelah diuji pada 11 jenis equation menunjukkan hasil dengan pola yang linier. Dengan demikian, seluruh hubungan memenuhi asumsi linieritas dalam penggunaan GSCA.

\subsection{Analisis Measure of Fit Measurement Model}

Measures of Fit pada variabel dengan model indikator bersifat reflektif didasarkan pada estimasi loading dan signifikansinya. Sedangkan untuk model indikator bersifat formatif didasarkan pada signifikansi weight indikatornya. Dalam penelitian ini, variabel Keputusan Adopsi TI, Implementasi Adopsi TI, dan Kinerja bersifat reflektif. Sedangkan variabel Faktor Internal dan Faktor Eksternal bersifat formatif. Hasil kelima indikator pada variabel faktor internal belum menunjukkan signifikansi bila dilihat pada nilai critical ratio $(\mathrm{CR})$ weight. Bila ditinjau dari nilai estimate weight pada masing-masing indikatornya, terdapat tiga indikator yang bernilai positif, sedangkan dua lainnya bernilai negatif. Nilai estimate paling besar yakni 0,567 yang diperoleh indikator Manajemen Puncak.

Hasil keempat indikator pada variabel faktor eksternal juga belum menunjukkan signifikansi bila dilihat pada nilai critical ratio (CR) weight. Tinjauan terhadap nilai estimate menunjukkan adanya tiga indikator yang bernilai positif dan terdapat satu indikator yang nilainya negatif. Indikator Lingkungan Kompetitif memperoleh nilai estimate weight terbesar untuk variabel ini, yakni 0,810. Pada variabel Keputusan Adopsi TI, level adopsi TI merupakan indikator dengan nilai estimate loading sebesar 0,857 dan signifikan dengan critical ratio sebesar 8,83 pada level 0,05 ( $\mathrm{p}<0,05)$. Sedangkan indikator ketersediaan TI memiliki nilai estimate loading sebesar 0,663 dan juga signifikan dengan critical ratio sebesar 2,41 pada level 0,05 ( $\mathrm{p}<0,05$ ). Maka dengan hasil tersebut dapat disimpulkan bahwa convergent validity kedua indikator tersebut baik dan tepat untuk mendeskripsikan variabel keputusan adopsi TI.

Pada variabel Implementasi Adopsi TI, indikator tingkat penggunaan TI memiliki nilai estimate loading sebesar 0,944 dan signifikan dengan critical ratio sebesar 57,42 pada level 0,05 (p < 0,05). Sedangkan indikator lama adopsi TI memiliki nilai estimate loading sebesar 0,929 dan juga signifikan dengan critical ratio sebesar 27,86 pada level 0,05 ( $\mathrm{p}<0,05$ ). Maka dengan hasil yang ditunjukkan pada kedua indikator tersebut, dapat disimpulkan bahwa convergent validity kedua indikator tersebut sangat baik. Kinerja berbasis pasar memiliki nilai estimate loading sebesar 0,899 dengan critical ratio sebesar 38,08 pada level 0,05 ( $\mathrm{p}<0,05)$, sehingga dapat dikatakan valid dan signifikan. Sedangkan kinerja berbasis operasional memiliki nilai estimate loading sebesar 0,901, yang berarti valid, dan juga signifikan dengan critical ratio sebesar 29,64 pada level 0,05 ( $<<0,05)$. Maka 
dengan hasil tersebut dapat disimpulkan bahwa kedua indikator tersebut memiliki convergent validity yang baik dan sesuai untuk mendeskripsikan variabel kinerja.

\subsection{Analisis Measure of Fit Structural Model}

Dari hasil analisis GSCA, nilai FIT sebesar 0,468 dapat diartikan bahwa model mampu menjelaskan 46,8\% variasi dari data yang ada. Dapat juga diartikan bahwa keragaman Faktor Internal, Faktor Eksternal, Keputusan Adopsi TI, dan Implementasi TI mampu mempengaruhi Kinerja sebesar $46,8 \%$ dan signifikan pada tingkat $95 \%$. Sedangkan sisanya sebesar $53,2 \%$ dapat dijelaskan oleh variabel yang lain. Dengan demikian, model dapat dikatakan cukup baik untuk menjelaskan fenomena yang dikaji dalam penelitian ini. Untuk nilai AFIT dalam penelitian ini $(0,451)$ dapat menjadi alternatif perbandingan untuk mengakomodasi keragaman variabel lainnya.

\subsection{Pengujian Hipotesis}

Pengujian Hipotesis pada GSCA didapatkan dari nilai yang ditunjukkan Path Coefficients pada measures of fit model struktural, yakni berdasarkan nilai signifikansi estimasi parameternya.

Nilai Path Coefficients pada GSCA untuk hubungan antar variabel dalam penelitian ini digambarkan lebih jelas dengan Gambar 2 di atas. Berdasarkan hasil yang diperoleh pada GSCA, kondisi tersebut mencerminkan bahwa hubungan faktor internal terhadap keputusan adopsi TI tidak signifikan. Hasil dari pengujian ini dapat disimpulkan bahwa faktor internal tidak terbukti berpengaruh terhadap keputusan adopsi TI di BPR, sehingga Hipotesis 1 dinyatakan ditolak. Hubungan faktor eksternal terhadap keputusan adopsi TI juga tidak signifikan. Dari pengujian ini dapat disimpulkan hasilnya bahwa faktor eksternal tidak terbukti berpengaruh terhadap keputusan adopsi TI di BPR, sehingga Hipotesis 2 dinyatakan ditolak. Untuk keputusan adopsi TI terhadap implementasi adopsi TI terdapat korelasi positif yang signifikan, terbukti dari hasil penelitian ini bahwa tahapan keputusan adopsi TI dapat berpengaruh terhadap tahapan berikutnya yaitu implementasi adopsi TI di BPR, maka Hipotesis 3 dinyatakan diterima. Sedangkan hubungan implementasi adopsi TI terhadap kinerja menunjukkan hasill yang tidak signifikan. Sehingga dari pengujian ini dapat ditarik kesimpulan bahwa implementasi adopsi TI tidak terbukti berpengaruh terhadap kinerja BPR, artinya Hipotesis 4 dinyatakan ditolak.

\subsection{Diskusi}

Adopsi TI membutuhkan investasi jangka panjang dalam jumlah yang tidak sedikit, hal ini yang kemudian memunculkan kekhawatiran bagi manajemen puncak BPR dalam mengambil keputusan terkait adopsi TI, karena disebabkan keterbatasan sumber daya keuangan yang dimiliki BPR. Berkaitan dengan kendala keuangan tersebut, akibatnya BPR juga mengalami kesulitan dalam mempekerjakan tenaga ahli TI untuk mengimplementasikan TI di lingkungan internal BPR.

Kesulitan dalam memperkirakan besarnya biaya TI juga akan memunculkan kekhawatiran terhadap manfaat yang akan diperoleh dari investasi TI. BPR, yang memiliki sumber daya keuangan terbatas, mengalami kesulitan dalam memperkirakan biaya TI yang perlu dialokasikan. Maka, pertimbangan terkait biaya TI ini kemungkinan akan menjadi pertimbangan penting dalam keputusan manajemen puncak untuk mengadopsi TI di BPR.

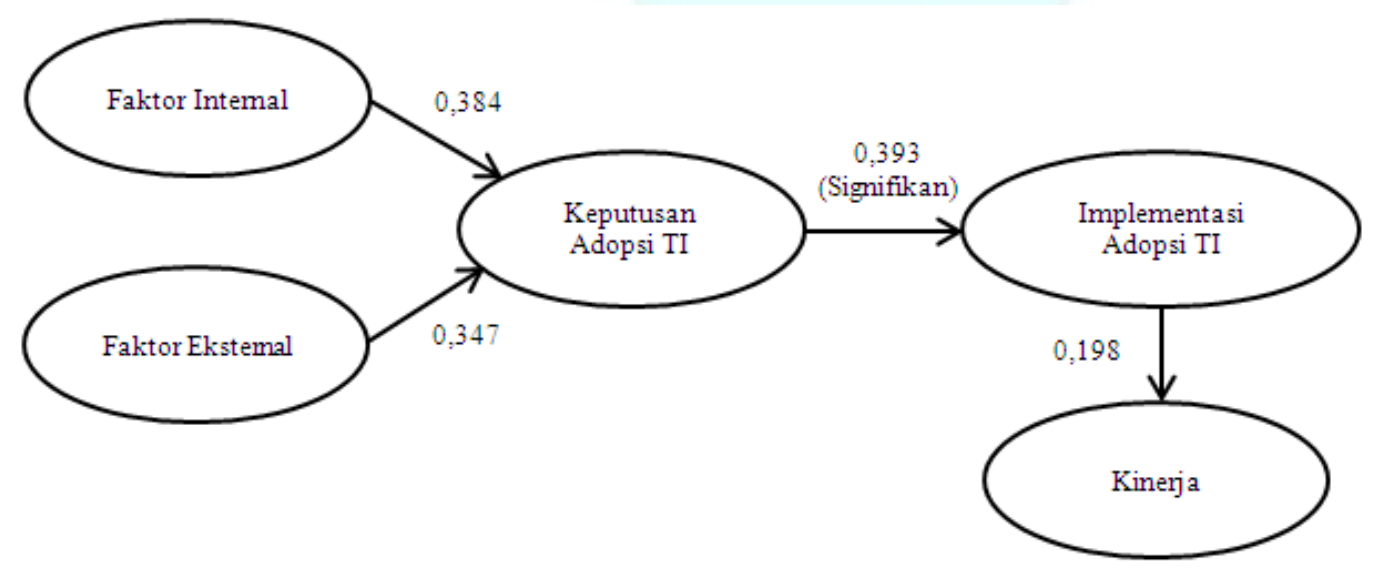

Gambar 2 Nilai Koefisien Jalur Model 
UKM memiliki keterbatasan dalam pengetahuan dan keahlian untuk menerapkan teknologi baru. Kondisi dalam BPR menunjukkan bahwa keberadaan konsultan TI belum dapat dimanfaatkan perannya guna menjembatani minimnya pengetahuan dan keahlian untuk mengadopsi TI. BPR lebih mempertimbangkan sumber daya keuangan yang tersedia karena umumnya memerlukan biaya yang cukup besar untuk menyewa konsultan TI luar. Hal ini akan menjadi pertimbangan menarik terkait keputusan manaje-men puncak untuk mengadopsi TI di BPR dengan adanya keterbatasan sumber daya internal yang memiliki pengetahuan dan keahlian TI yang memadai.

Keberhasilan implementasi adopsi TI dalam hal ini dapat dicermati dari tingkat penggunaan TI dalam kurun waktu tertentu. Dalam rangka meningkatkan penggunaan TI di BPR, maka manajemen puncak perlu menguatkan niat dan motivasi dari pengguna untuk menggunakan TI tersebut. Dalam pelaksanaannya, kecepatan pengguna dalam beradaptasi dengan TI diyakini dapat memudahkan pengguna dalam menggunakan TI tersebut. Bila pengguna telah mampu beradaptasi dengan baik terhadap TI yang digunakan, maka selama kurun waktu tertentu dapat terbentuk kebiasaan pengguna dalam penggunaan TI di BPR.

Dalam hal kinerja keuangan, pencapaian kinerja bila dibandingkan dengan pesaing juga masih sulit dicermati oleh manajemen puncak. Hal ini diduga karena kebutuhan informasi pada ranah strategis belum dapat diakomodasi melalui implementasi TI, karena TI di BPR diimplementasikan sejauh untuk mendukung aktivitas bisnis pada ranah teknis yang terkait pendanaan (tabungan dan deposito), penyaluran (kredit dan pinjaman), dan dokumentasi keuangan (pencatatan dan laporan).

\section{SIMPULAN DAN SARAN}

Simpulan yang dapat diambil dari penelitian ini adalah faktor internal BPR tidak terbukti berpengaruh terhadap keputusan adopsi TI di BPR. Faktor internal yang paling besar berpengaruh terhadap keputusan adopsi TI tidak dapat diketahui, karena hasilnya tidak signifikan. Namun, indikator yang paling dominan dalam membentuk faktor internal ini ialah Manajemen Puncak BPR. Faktor eksternal BPR tidak terbukti berpengaruh terhadap keputusan adopsi TI di BPR. Faktor eksternal yang paling besar berpengaruh terhadap keputusan adopsi TI tidak dapat diketahui, karena hasilnya tidak signifikan. Namun, indikator yang paling dominan dalam membentuk faktor eksternal ini ialah Lingkungan Kompetitif. Keputusan adopsi TI terbukti berpengaruh terhadap implementasi adopsi TI di BPR. Hasil penelitian ini menunjukkan bahwa antara keputusan adopsi TI dan implementasi adopsi TI terdapat korelasi positif yang signifikan. Implementasi adopsi TI tidak terbukti berpengaruh terhadap kinerja BPR. Kondisi ini mengindikasikan bahwa tingkat penggunaan TI selama kurun waktu tertentu yang tergambar dalam tahap implementasi adopsi TI ini tidak dapat diketahui secara pasti sejauh mana dapat memberikan kontribusi pada peningkatan kinerja BPR

Saran untuk penelitian berikutnya adalah faktorfaktor yang dapat berpotensi mempengaruhi keputusan adopsi TI selain dikategorikan ke dalam aspek internal dan eksternal, disarankan juga dapat dipilah menjadi faktor pendukung atau penghambat di dalam masing-masing aspeknya. Terkait kinerja keuangan BPR yang ditinjau dari aset bisnis, bagaimana caranya dalam penelitian mendatang dapat menangkap celah perbedaan kondisi implementasi adopsi TI pada BPR yang mengalami peningkatan jumlah aset dalam beberapa tahun terakhir dengan kondisi implementasi adopsi TI pada BPR yang mengalami penurunan jumlah aset. Pada penelitian mendatang, penggalian data yang dilakukan dapat memperhatikan dan memilah item-item dari instrumen penelitian, mana yang membutuhkan persepsi responden dengan kuesioner dan mana yang berupa data aktual yang dapat diperoleh dari selain kuesioner. Penelitian terkait adopsi TI pada UKM di Indonesia dapat dikembangkan lebih luas lagi baik dari jenis UKM maupun dari jumlah populasi dan sampelnya.

\section{DAFTAR RUJUKAN}

Al-Gahtani, S. S., Hubona, G. S., and Wang, J. (2007). Information technology (IT) in Saudi Arabia: Culture and the acceptance and use of IT. Information and Management, 44(8), 681-691.

DeLone W. \& McLean E. 2003, "The DeLone and McLean Model of Information Systems Success: A Ten-Year Update", Journal of Management Information Systems 19(4), 930.

Ghobakhloo, M; Sabouri, M.S; Hong T.S; Zulkifli, N. 2011, "Information Technology Adoption in Small and Medium-sized Enterprises; An Appraisal of Two Decades Literature", Interdisciplinary Journal of Research in Business, Vol. 1, Issue. 7, July 2011(pp.53-80).

Khristianto, W., 2012. Penggunaan Teknologi Informasi di Usaha Kecil dan Menengah. 
Levy, M. \& Powell, P. 2005, Strategies for Growth in SMEs: The Role of Information and Information Systems, Elsevier Butterworth and Heinemann, Amsterdam.

Ogalo, J.O; Asaka, C.N; Aila, F.O. 2011, "Relationship between use of Information Communication Technologies (ICT) and the performance of small enterprises in Kisumu City", Prime Journal of Business Administration and Management (BAM) Vol. 1 (7), pp. 198-204.

Robbins, S.P. 2003, Organizational Behavior, 10th edn, Prentice Hall, Upper Saddle River.

Rogers, E.M. 1995, Diffusion of Innovations, 4th edn, Free Press, New York.

Subriadi, A.P. et al, 2013, "Firm Age, Firm Size and Information Technology Intencity
Industry Factors in Influencing Information Technology Contribution to Improve Performance", Journal of Thepretical and Applied Information Technology Vol. 54 No.3.

Sarosa, S., and Zowghi, D., 2003. Strategy for adopting information technology for SMEs: Experience in adopting email within an Indonesian furniture company. Electronic Journal of Information Systems Evaluation, 6(2), 165-176.

Wang, W.; Chang, C.; Heng, M.2004, "The Levels Of Information Technology Adoption, Business Network, And A Strategic Position Model For Evaluating Supply Chain Integration", Journal of Electronic Commerce Research, VOL. 5, NO.2, 2004. 